\title{
Surface Microstructure of Mo(C)N Coatings Investigated by AFM
}

\author{
T. Kuznetsova, T. Zubar, S. Chizhik, A. Gilewicz, O. Lupicka, and B. Warcholinski
}

\author{
(Submitted May 17, 2016; in revised form October 4, 2016; published online October 18, 2016)
}

\begin{abstract}
MoCN coatings have been formed by cathodic arc evaporation using the mixture of acetylene and nitrogen and pure molybdenum target. The surface structure, in conjunction with $x$-ray data, was analyzed by atomic force microscopy (AFM). The AFM results show differently shaped grain forms on the surface of coatings investigated. The increase in carbon in chemical coatings composition results in the reduction in surface grain size and the increase in roughness of the coatings.
\end{abstract}

Keywords AFM, microstructure, MoCN coating

\section{Introduction}

One of the ways to improve mechanical and tribological tools' and machine parts properties is surface's modification by a thin hard coating deposition. The properties of two-component coatings are often not able to meet the users' requirements. They can be improved, for example by changing the chemical composition (adding the third or more elements to two-element system) or by changing the coating structure by the choice of process parameters. In the latter case, for example, grain refinement (Ref 1) or forming the nanostructured composite coatings may occur (Ref 2). Such coatings may show low coefficient of friction, high wear resistance and high hardness.

Transition metals nitrides and carbides formed using PVD methods show good tribological and mechanical properties, including high hardness, low coefficient of friction, excellent wear and corrosion resistance, as well as characteristic color. For this reason, they are widely used as protective and decorative coatings (Ref 3-6). One of them is molybdenum nitride. High hardness and good adhesion, low coefficient of friction especially at higher temperature (Ref 7) and low wear rate make the coating a good candidate for the wide range of tribological applications.

Dependent on the chemical composition in Mo-N system, the existence of the following phases can be expected: spacecentered cubic lattice of molybdenum Mo [JCPDS 42-1120], tetragonal-centered cubic phases: $\beta-\mathrm{Mo}_{2} \mathrm{~N}$ [JCPDS 24-0768], $\beta^{\prime}-\mathrm{Mo}_{2} \mathrm{~N}$ [JCPDS 25-1368], $\beta^{\prime \prime}-\mathrm{Mo}_{2} \mathrm{~N}$ [JCPDS 75-1150], cubic $\gamma-\mathrm{Mo}_{2} \mathrm{~N}$ [JCPDS 25-1366], hexagonal $\delta$-MoN [JCPDS 251367] and cubic phase marked B1 MoN (Ref 8). The tetragonal phases $\beta-\mathrm{Mo}_{2} \mathrm{~N}$ are low-temperature variations of the $\gamma-\mathrm{Mo}_{2} \mathrm{~N}$

T. Kuznetsova, T. Zubar, and S. Chizhik, A. V. Luikov Heat and Mass Transfer Institute of the National Academy of Sciences of Belarus, Minsk, Belarus; and A. Gilewicz, O. Lupicka, and B. Warcholinski, Faculty of Technology and Education, Koszalin University of Technology, Koszalin, Poland. Contact e-mail: bogdan.warcholinski@tu.koszalin.pl. cubic phase. Due to different crystallographic structures, the phases exhibit different physical properties.

Studies on the effects of small amounts of elements such as $\mathrm{C}, \mathrm{Si}, \mathrm{Cu}, \mathrm{B}$, and others on the mechanical and tribological properties of $\mathrm{CrN}$ and $\mathrm{TiN}$ coatings have shown that such coatings have higher hardness and lower coefficient of friction (Ref 9-11). Carbon as a further component of the coating causes the change in morphology of the coating, but also affects the sliding behavior due to its low-friction properties.

Molybdenum carbide except for high hardness (Ref 12), corrosion resistance and high thermal stability also show catalytic properties (Ref 13). Zhao et al. (Ref 14) reported that carbon addition to MoCN enables to obtain nanomaterials with reduced grain size, dense active sites and high surface area. Some of above findings were confirmed by Liu et al. (Ref 12).

The properties of Mo-C-Si-N quaternary compositions (Ref 15) depend on carbon concentration. With the increase in $\mathrm{C}$ concentration, the average coefficient of friction and grain size decreases, while the hardness increases. Authors conclude that carbon atoms substitute nitrogen atoms in the nano-sized crystalline $\mathrm{Mo}_{2} \mathrm{~N}$ to form $\mathrm{Mo}_{2} \mathrm{~N}(\mathrm{C})$ solid solution phase. They also suggest that in the amorphous $\mathrm{SiN}_{\mathrm{x}}$ and $\mathrm{CN}_{\mathrm{x}}$ phases nanosized crystalline $\mathrm{Mo}_{2} \mathrm{~N}(\mathrm{C})$ may be embedded.

The investigations of MoCN-Ag coatings (Ref 16, 17) indicate that the self-lubricating coatings significantly reduce the coefficient of friction, especially at elevated temperature, above $400{ }^{\circ} \mathrm{C}$ due to formation of molybdenum oxide and silver molybdate. A free amorphous carbon phase is responsible for low coefficient of friction up to $100{ }^{\circ} \mathrm{C}$.

The properties of materials depend on their structure and microstructure determined by the chemical composition, the atomic structure of constituent phases. The microstructure can be modified by the technologies of production and the material processing. Therefore, the design and the production of new materials should be in control with their microstructure in order to assess the requirements compatibility with the result of the manufacturing process. This allows to detect both their formation mechanism and their behavior during operation. The method of atomic force microscopy (AFM) meets high requirements for investigation of thin vacuum coating deposited on polished substrates (Ref 18, 19). It allows not only to investigate topography of coating surface with nanometer resolution but also to detect heterogeneity in tribological surface properties caused by the presence of different phases in the coating. 
Table 1 Relationship between acetylene flow rate, carbon concentration in the coatings (Ref 16) and denotation of the coatings

\begin{tabular}{lcl}
\hline $\begin{array}{l}\mathbf{C}_{2} \mathrm{H}_{2} \text { flow rate, } \\
\text { sccm }\end{array}$ & $\begin{array}{c}\text { Carbon } \\
\text { concentration, at. } \%\end{array}$ & \multicolumn{1}{c}{$\begin{array}{c}\text { Coating } \\
\text { notation }\end{array}$} \\
\hline 0 & 0 & $\mathrm{Mo}_{0.68} \mathrm{~N}_{0.32}$ \\
5 & 7.1 & $\mathrm{Mo}_{0.64} \mathrm{C}_{0.07} \mathrm{~N}_{0.29}$ \\
10 & 13.5 & $\mathrm{Mo}_{0.56} \mathrm{C}_{0.14} \mathrm{~N}_{0.30}$ \\
15 & 16.2 & $\mathrm{Mo}_{0.54} \mathrm{C}_{0.16} \mathrm{~N}_{0.30}$ \\
20 & 18.5 & $\mathrm{Mo}_{0.53} \mathrm{C}_{0.19} \mathrm{~N}_{0.28}$ \\
\hline
\end{tabular}

The aim of this work was to study the surface microstructure of $\mathrm{Mo}(\mathrm{C}) \mathrm{N}$ coatings using $\mathrm{AFM}$ technique. To the best of our knowledge, $\mathrm{Mo}(\mathrm{C}) \mathrm{N}$ coatings have not been investigated using mentioned technique.

\section{Experimental Details}

Molybdenum carbonitride coatings were formed by introducing acetylene $\left(\mathrm{C}_{2} \mathrm{H}_{2}\right)$ in the vacuum chamber of deposition system TINA 900M, using cathodic arc evaporation. All technological

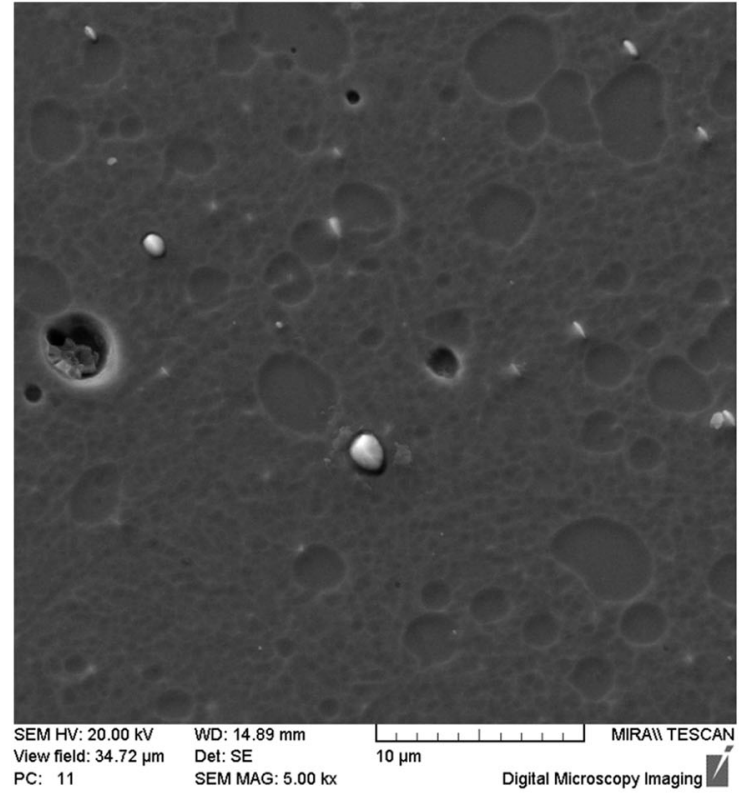

(a)

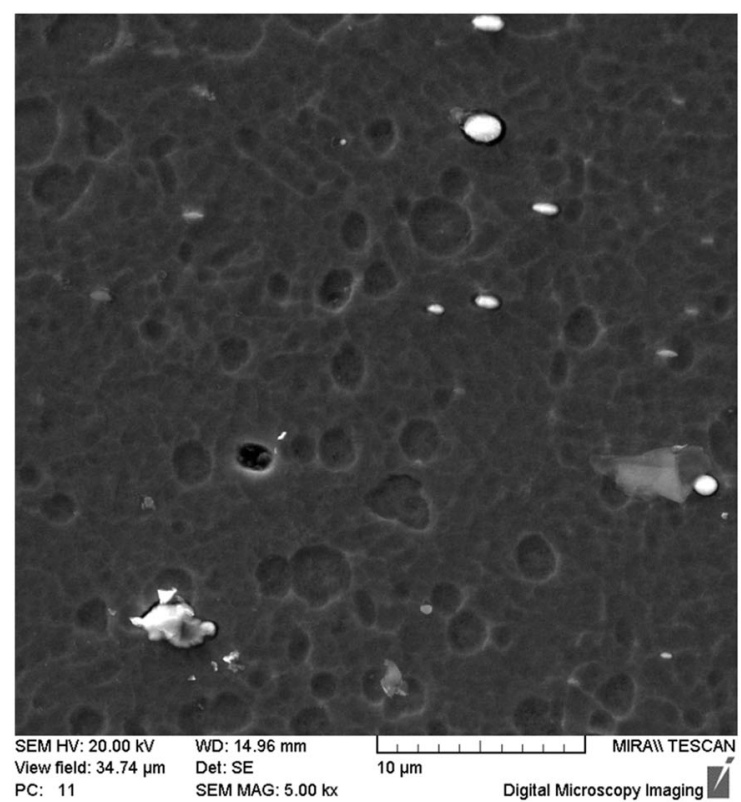

(c)

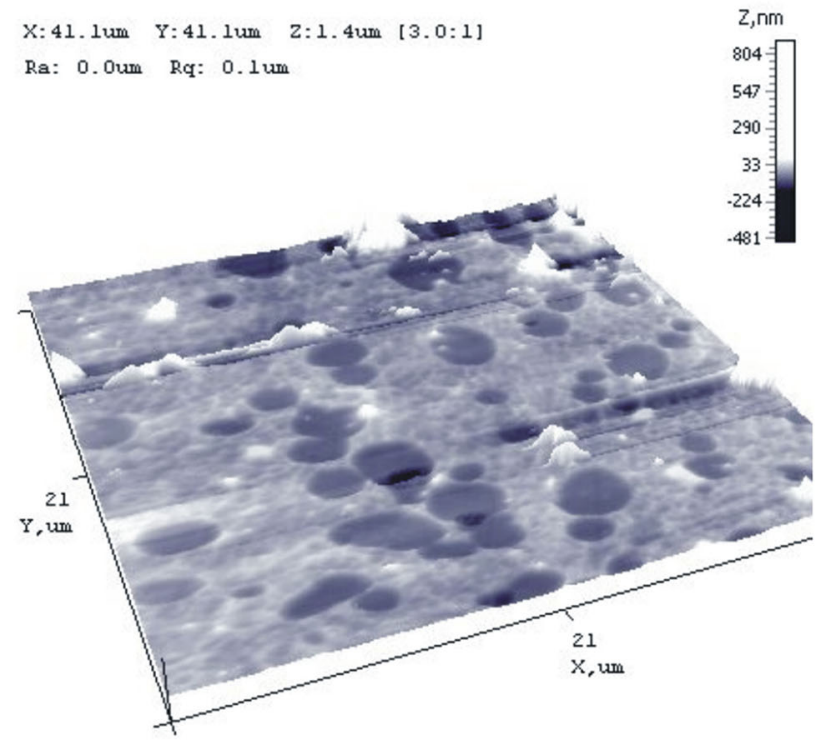

(b)

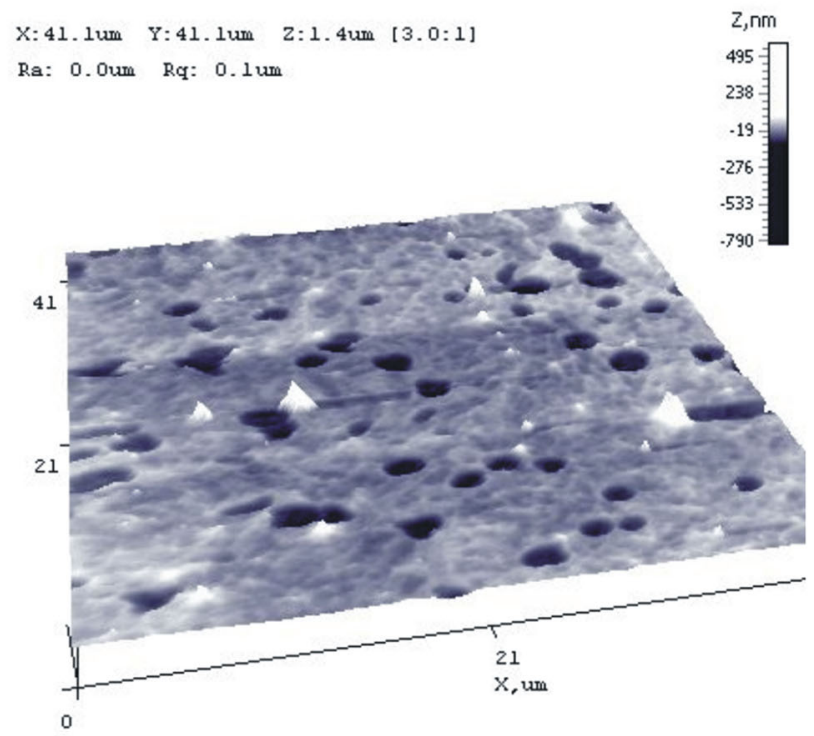

(d)

Fig. 1 Comparison of SEM and AFM microstructure of Mo(C)N coatings: (a) 7.1 at.\% C, SEM, magnification $\times 5000$; (b) 7.1 at.\% C, AFM, scanning area $40 \times 40 \mu \mathrm{m}$; (c) 18.5 at. $\%$ C, SEM, magnification $\times 5000$; (d) 18.5 at. $\%$ C, AFM, scanning area $40 \times 40 \mu \mathrm{m}$ 


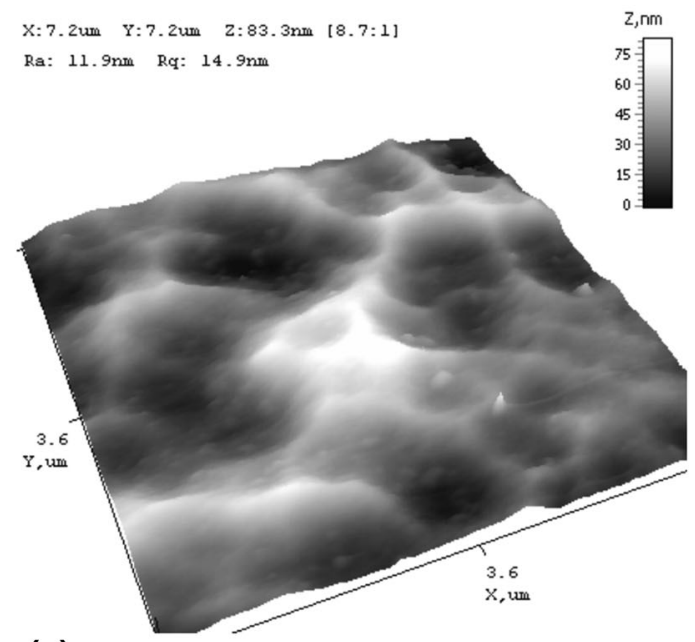

(a)
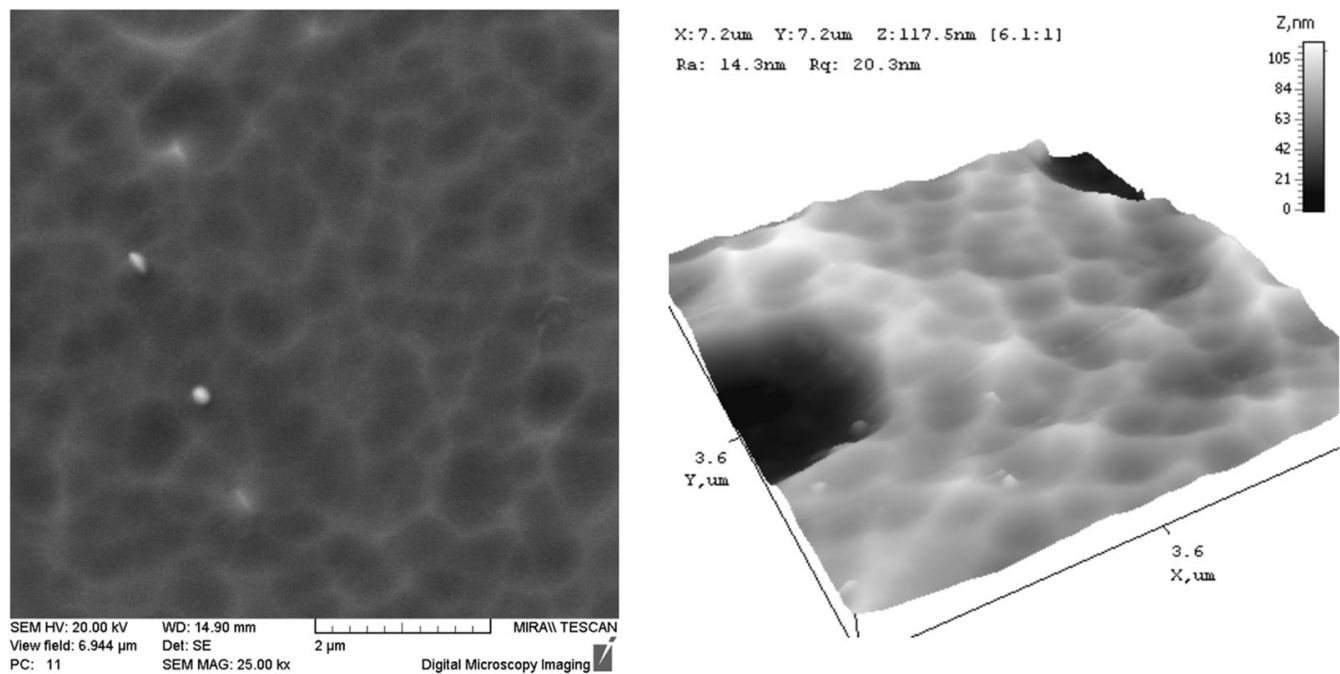

(b)

(c)

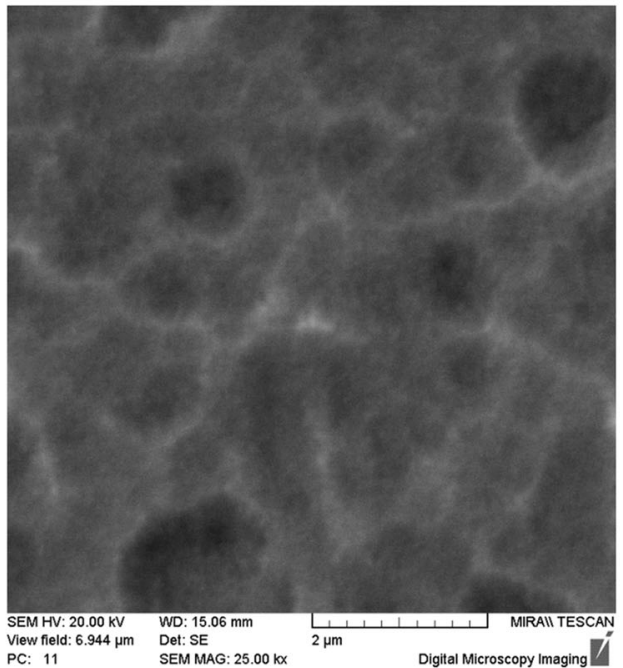

(d)

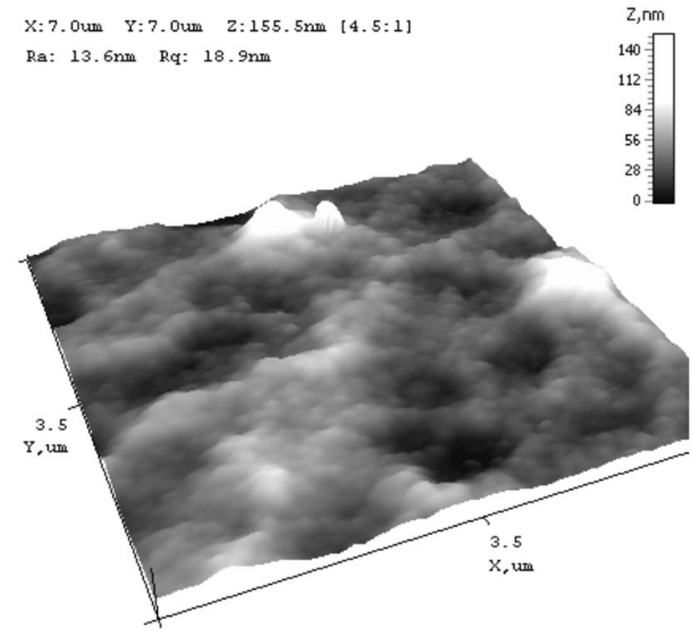

(e)

Fig. 2 Comparison of SEM and AFM microstructure of $\mathrm{Mo}(\mathrm{C}) \mathrm{N}$ coatings on the area $7 \times 7 \mu \mathrm{m}$ : (a) 0 at.\% C, AFM; (b) 7.1 at.\% C, SEM; (c) 7.1 at.\% C, AFM; (d) 18.5 at.\% C, SEM; (e) 18.5 at.\% C, AFM 
Table 2 Roughness of $\mathrm{Mo}(\mathrm{C}) \mathrm{N}$ coatings investigated by AFM on the scanning area $40 \times 40 \mu \mathrm{m}$

\begin{tabular}{lc}
\hline Flow of $\mathbf{C}_{\mathbf{2}} \mathbf{H}_{2}$, sccm & Roughness, $\mathbf{n m}$ \\
\hline 0 & $27 \pm 3$ \\
5 & $35 \pm 5$ \\
10 & $31 \pm 8$ \\
15 & $32 \pm 2$ \\
20 & $38 \pm 13$ \\
\hline
\end{tabular}

details and results of chemical composition investigations are shown in (Ref 20). The thickness $\mathrm{Mo}(\mathrm{C}) \mathrm{N}$ coating deposited on HS6-5-2 steel substrates is about $3 \mu \mathrm{m}$. The relationship between the flow of $\mathrm{C}_{2} \mathrm{H}_{2}$ in vacuum chamber and the carbon concentration in $\mathrm{Mo}(\mathrm{C}) \mathrm{N}$ coatings is presented in Table 1 .

The investigation of topography of $\mathrm{Mo}(\mathrm{C}) \mathrm{N}$ coating using atomic force microscopy (AFM) was provided on NT-206 device (produced by MTM Belarus). As a result of scanning the surface in contact regime, two types of data are recorded in two different files: a normal deflection of cantilever and a cantilever twist. The normal deflection arises because of the surface relief. The twist of cantilever arises because of present forces between the surface and the tip (Ref 21). The normal deflection forms the topography image. The lateral projection of cantilever twist forms the image of lateral forces named "Torsion." The main part of the lateral forces is friction force. Friction force is joined effect of elasticity, adhesion, viscosity, capillary forces, surface chemistry, electrostatic interaction and so on. The first or the second phenomenon occurs dependent on the conditions and material dominated. So the cantilever twist is caused by surface properties. This "Torsion" regime can be used for a distinction of different phases in $\mathrm{Mo}(\mathrm{C}) \mathrm{N}$ as a phase is a region of space in which all physical properties of a material are uniform. The phase according to AFM is a region of the surface with a boundary which has the same color. One color means one angle of cantilever twist. The value of cantilever twist depends on cantilever stiffness. The silicon cantilevers of CSC 38 type (Micromasch, Estonia) with stiffness coefficient $k=0.08 \mathrm{~N} / \mathrm{m}$ were used in this research. The phases recorded using AFM were compared with phases recorded and identified in X-ray diffraction (XRD). AFM gives a map of the surface with particles and regions of different colors (white, gray, dark). $\mathrm{x}$-ray analysis helps to choose the possible chemical formula of the phase. As the silicon cantilever is very sensitive, it is possible to discriminate more phases on the thin coating surface than according to XRD. The roughness measurements were conducted on five randomly selected areas.

Preliminary tests of wear using AFM equipped in diamond tip with radius about $200 \mathrm{~nm}$ were performed on selected coatings on the scan area $5 \times 5 \mu \mathrm{m}^{2}$ with load about $2 \mathrm{mN}, 3$ scans at the same place, 128 lines in scan and average scan velocity about $14.8 \times 10^{-6} \mathrm{~m} / \mathrm{s}$. The specific wear rate was calculated according to Archard's formula.

Surface microstructure was investigated using scanning electron microscope "Mira" produced by Tescan (Czech Republic).

\section{Results and Discussion}

The high-resolution method of scanning electron microscopy (SEM) does not allow significant differentiation in the microstructure of the $\operatorname{Mo}(\mathrm{C}) \mathrm{N}$ coatings obtained with different volume of acetylene in the vacuum chamber. The main structural features of these coatings at the magnification of $\times 5000$ are microdroplets, craters after chipping of microdrops, spherical particles of oxides (Fig. 1).

The fraction of microdroplet phase in $\mathrm{Mo}(\mathrm{C}) \mathrm{N}$ coatings amounts to several percent, and it does not manage to determine the differences according to this criterion. When assess the microstructure of coating surface according to SEM images with magnification of $\times 25000$, it is only possible to make conclusion that protruding borders of cells are the most developed and have the smallest cells size about $600 \mathrm{~nm}$ for the coating with 7.1 at.\% of carbon. In coating with 13.5 at.\% C, the borders are poorly visible. The developed borders in this coating are very rare. In coating with 18.5 at. $\% \mathrm{C}$, the borders achieve the biggest size of about $1 \mu \mathrm{m}$ (Fig. 2).

The use of AFM on the scanning field with size from $20 \times 20 \mu \mathrm{m}$ till $40 \times 40 \mu \mathrm{m}$ enables to assess only the depth of craters after chipping of microdrops (Fig. $1 \mathrm{~b}$ and d). It is 50$120 \mathrm{~nm}$. Like in SEM images, in AFM images the largest crater diameters of about $5 \mu \mathrm{m}$ are in the coating obtained with 5 $\mathrm{sccm}$ acetylene flow. The smallest crater diameters of about 2 $\mu \mathrm{m}$ are in coating with $20 \mathrm{sccm} \mathrm{C}_{2} \mathrm{H}_{2}$ flow. The coatings obtained with 10 and $15 \mathrm{sccm}$ acetylene flow have irregular distribution of craters (Fig. 1b and d).

The values of roughness $\mathrm{Mo}(\mathrm{C}) \mathrm{N}$ coatings obtained by AFM on areas $40 \times 40 \mu \mathrm{m}$ are in Table 2. It should be noted that roughness determined using $\mathrm{AFM}$ technique for $\mathrm{Mo}(\mathrm{C}) \mathrm{N}$ coating deposited without acetylene flow rate in the same technological conditions is similar. For $\mathrm{Mo}_{0.68} \mathrm{~N}_{0.32} \mathrm{Ra}$ was determined using contact recording instrument (Hommel Werke T8000) and amounts to about $0.04 \mu \mathrm{m}(\operatorname{Ref} 22)$.

But in the case of AFM, undetected features of the coating which is formed under $\mathrm{C}_{2} \mathrm{H}_{2}$ flow are only the problem of the right size scanning area selection. The use of the scanning area $5 \times 5 \mu \mathrm{m}$ enabled to register the difference in the microstructure of $\mathrm{Mo}(\mathrm{C}) \mathrm{N}$ coating formed at different acetylene flow rate in vacuum chamber (Fig. 3). That difference reflects the influence of the main deposition parameters and mainly the energy of bombardment on the coating formation. Two competing processes occur-deposition and resputtering of the coating. As an effect of resputtering are well-shaped cavities. The border of grain as a more harder material is resputtered slower than the softer body of grains. During the ion bombardment, the atoms from horizontal surfaces are resputtered easier than the atoms from vertical surfaces. Therefore the surface obtained by AFM as $3 \mathrm{D}$ images is interpreted as a multi-cell structure in which lowered bottom of the cells (core grain) and elevated vertical grain boundaries are visible.

The microstructure of MoN coating obtained without acetylene consists of "cells" characterized by relatively large size - about $2 \mu \mathrm{m}$ (Fig. 3a), completely randomly arranged. In coating deposited at $5 \mathrm{sccm} \mathrm{C}_{2} \mathrm{H}_{2}$ flow, the cells with smaller size, about $700 \mathrm{~nm}$ (Fig. 3b), are formed. The increased flow rate of the acetylene in the vacuum chamber results in additional carbon atoms which give rise in the number of crystallization nuclei on the surface of the formed coating. The density of the crystallization centers grows, and the formation of ridges is faster than without acetylene. The growing ridges form ordered cells of smaller size than without carbon. Around one cell, there are usually about six other cells. As a result, grains in size of about 100-200 nm appear in the microstructure of the coatings deposited with $10,15,20 \mathrm{sccm}$ of acetylene 


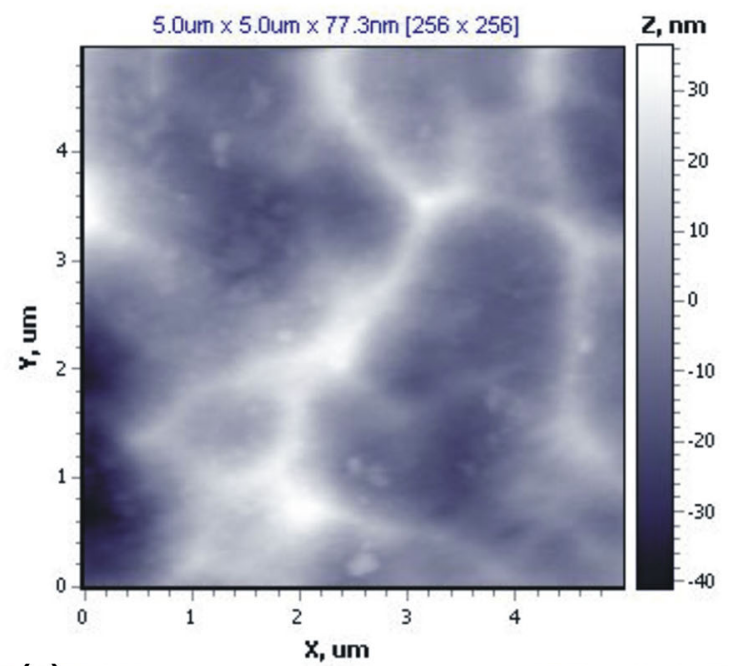

(a)

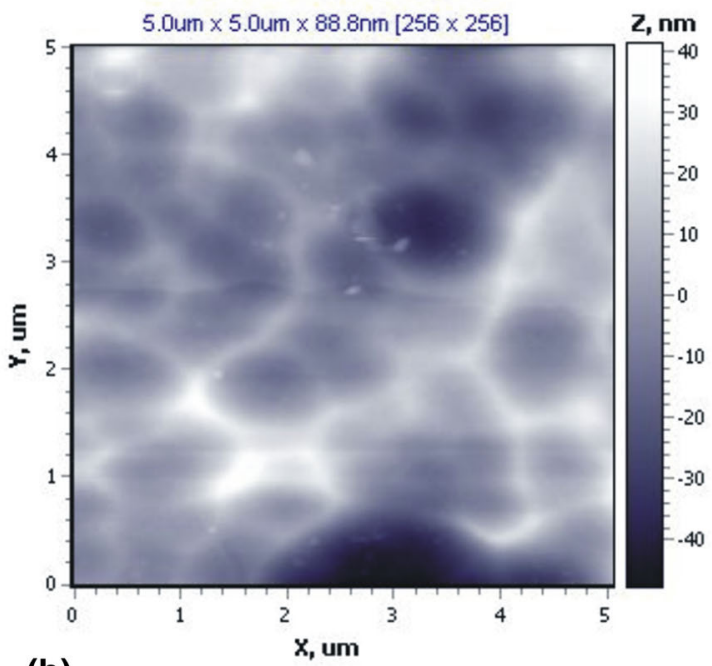

(b)
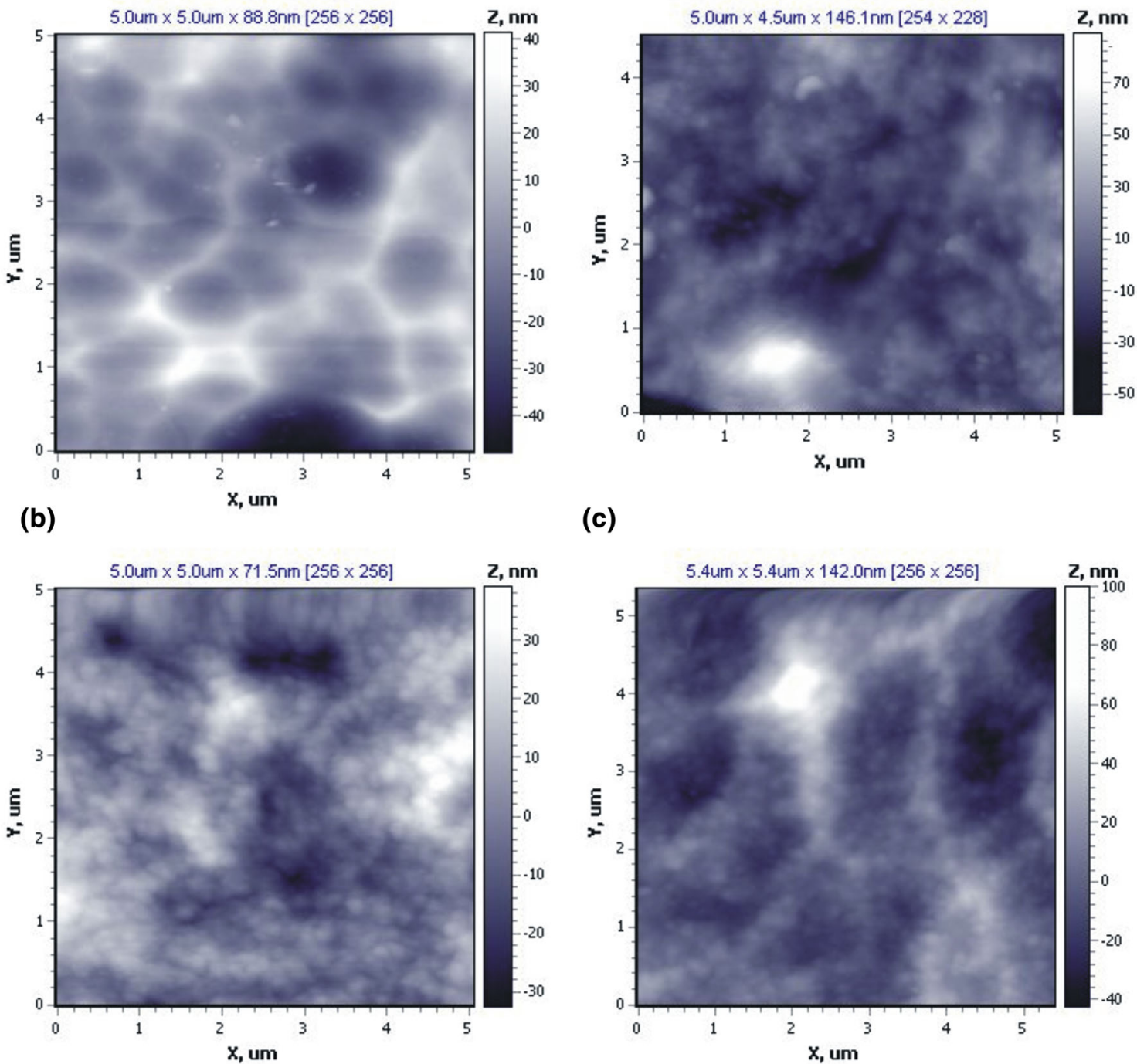

(c)

(d)

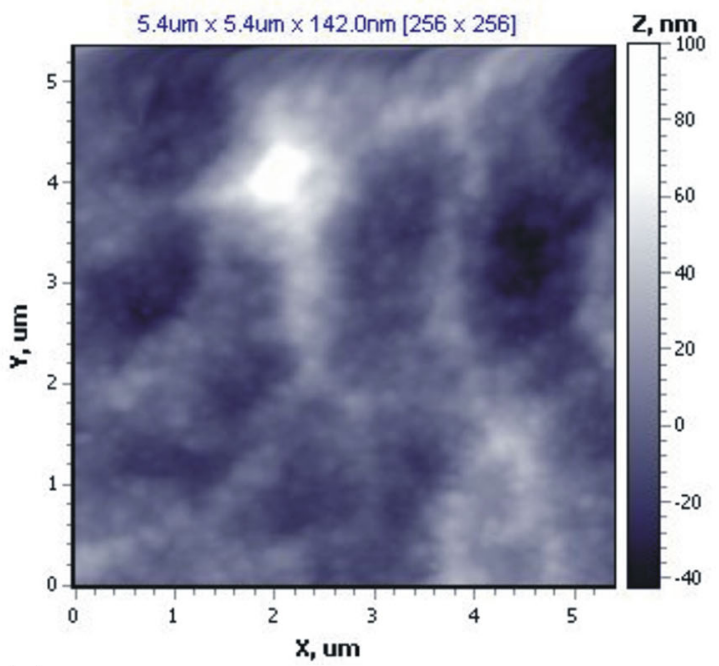

(e)

Fig. 3 AFM microstructure of $\mathrm{Mo}(\mathrm{C}) \mathrm{N}$ coatings, scanning area $5 \times 5 \mu \mathrm{m}$ : (a) $0 \%$ at. C; (b) 7.1 at.\% C; (c) 13.5 at.\% C; (d) 16.2 at.\% C; (e) 18.5 at. $\% \mathrm{C}$ 


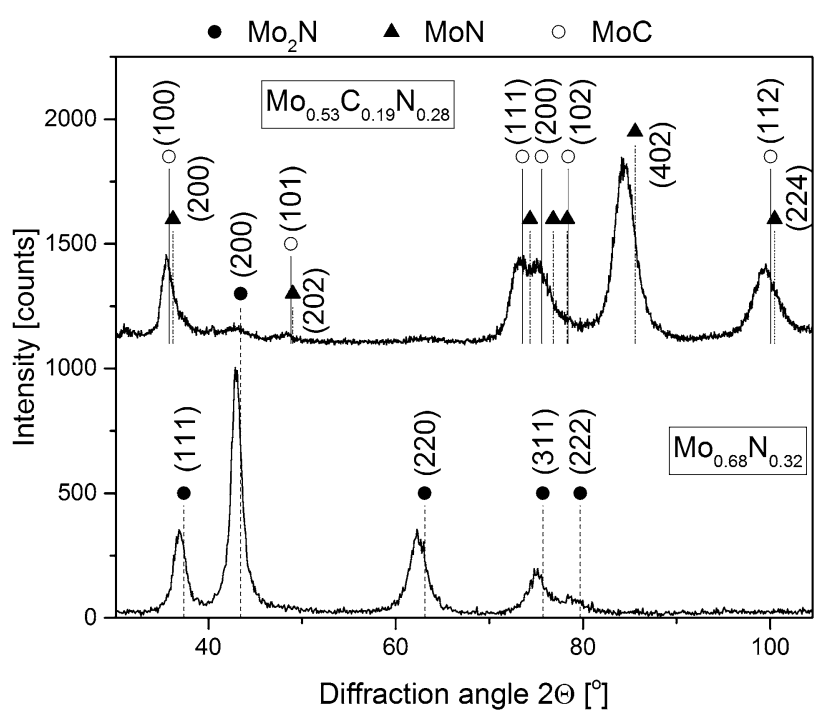

Fig. 4 XRD patterns of $\mathrm{Mo}_{0.68} \mathrm{~N}_{0.32}$ and $\mathrm{Mo}_{0.53} \mathrm{C}_{0.19} \mathrm{~N}_{0.28}$ coatings formed using cathodic arc evaporation

flow. The carbon content increase in the coating leads to more ordered microstructure. In coating deposited at $10 \mathrm{sccm} \mathrm{C}_{2} \mathrm{H}_{2}$ flow, the grains are located randomly (Fig. 3c), but in coating deposited at $15 \mathrm{sccm} \mathrm{C}_{2} \mathrm{H}_{2}$ flow the fragments of linear chain of grains can be seen, Fig. 3(d). In coating obtained with $20 \mathrm{sccm}$ $\mathrm{C}_{2} \mathrm{H}_{2}$ flow, small grains with diameter of 100-200 nm are located into border of grains sized in a range 0.5-1.5 $\mu \mathrm{m}$ (Fig. 3e). In this coating, the grains are ordered into the honeycomb-like structure.

The usage of AFM regime "Torsion" (or Lateral Forces) allows to visualize different phases on the surface of $\mathrm{Mo}(\mathrm{C}) \mathrm{N}$ coatings. The comparison of AFM data in "Torsion" regime with XRD data allows to get a distribution map of different phases in $\mathrm{Mo}(\mathrm{C}) \mathrm{N}$ coating (Ref 20).

According to the phase diagram and $\mathrm{XRD}$ results, the coating without carbon is characterized by cubic $\mathrm{Mo}_{2} \mathrm{~N}$ phase. But in the range of angles $72^{\circ}-82^{\circ}$, some diffraction lines exist, which are broadened, shifted and overlay themselves (Fig. 4).

Despite the fact that according to the diffraction pattern on the surface of coating there are not any other phases, in AFM images (Fig. 5a) in the structure of MoN coating three types of phases can be visible: gray phase (indicator 1, Fig. 5a), which is both the background for white phase in size of about 100-400 $\mathrm{nm}$ (indicator 2, Fig. 5a) and dispersed black phase in size of about $50 \mathrm{~nm}$ (indicator 3, Fig. 5a). It can be supposed that the black phase is $\mathrm{MoN}$. The white phase can be not quite stoichiometric phase or can be formed by some individual parts in the coating with the main cubic $\mathrm{Mo}_{2} \mathrm{~N}$ phase.

Based on the results (Ref 19) in which it was found that during nitriding of molybdenum in terms of saturation with nitrogen to temperature of $940{ }^{\circ} \mathrm{C}$ two layers: the outer layer of $\mathrm{MoN}$ and inner of $\mathrm{Mo}_{2} \mathrm{~N}$ were formed on the surface, we assume that fine black grains (phase) can be attributed to MoN. The same effect occurs in case of tungsten (Ref 23).

The existence of different phases on the coatings surface can be confirmed by findings of Yuan et al. (Ref 15) who suggest that carbon atoms substitute nitrogen atoms in the nano-sized crystalline $\mathrm{Mo}_{2} \mathrm{~N}$ to form $\mathrm{Mo}_{2} \mathrm{~N}(\mathrm{C})$ solid solution phase.

In fact the $\mathrm{C}_{2} \mathrm{H}_{2}$ flow of $5 \mathrm{sccm}$ during deposition does not change the phase composition of the coating. It leads to the increase in formation of all nitride phases. Based on the intensity of the diffraction lines such as (111) expected at $33.38^{\circ}$ for $\mathrm{Cu}-\mathrm{K} \alpha$ radiation, $(200)$ at $43.45^{\circ}$ or $(220)$ at $63.11^{\circ}$ according to ICDD 25-1366 it can be stated that this coating consists mainly of the cubic $\mathrm{Mo}_{2} \mathrm{~N}$ phase. In contrast, the next diffraction line (311) positioned at $75.73^{\circ}$ is more interesting. Its intensity increases and slightly broadens. It may be caused by the formation of MoC and/or MoN phase, but the amount of these compounds could be insufficient to be register by XRD. Such an increase in formation of nitride phases with the addition of small amount (5 sccm $\mathrm{C}_{2} \mathrm{H}_{2}$ flow) of carbon is reflected in the structure in form of grain size decrease, what is apparent in AFM image. The increase in carbon concentration in $\mathrm{Mo}(\mathrm{C}) \mathrm{N}$ coatings leads both to the appearance of larger crystallization centers quantity on the surface and to the decrease in grains size. In the microstructure of the surface, the grain size decrease is visualized in form of cells size decrease from 3 to $5 \mu \mathrm{m}$ for molybdenum nitride coating without carbon (Fig. 3a) to 1-2 $\mu \mathrm{m}$ for molybdenum nitride coating with carbon amount of 7.1 at.\% $\left(\mathrm{C}_{2} \mathrm{H}_{2}\right.$ flow rate of $\left.5 \mathrm{sccm}\right)$, Fig. 3(b). There are also more developed ridges of grains in this coating. The quantity of ridges increases, and it leads to surface roughness rise from 29.3 to $46.5 \mathrm{~nm}$ on the area of $40 \times 40 \mu \mathrm{m}^{2}$ (Table 1). In AFM "Torsion" regime, the quantity of phases, which are contrasted with the main phase, increases. Moreover, their size also decreases and the main phase is $\mathrm{Mo}_{2} \mathrm{~N}$. In AFM image, the phase has gray contrast and consists of nanosized subgrains with diameter of 20-50 nm (indicator 1, Fig. 5b). As it was mentioned above, the diffraction lines are broadened and shifted to lower angles from their positions. It can be associated with the nanosized structure of coating. They are different in forms and color types of particles from the others phases in the background of main $\mathrm{Mo}_{2} \mathrm{~N}$ phase as dispersed dark particles with diameter of $20-50 \mu \mathrm{m}$ so as lamellar bright particles with diameter 300-500 nm (indicator 2, Fig. 5b). They confirm the possibility of the existence of MoN and MoC phases (Fig. 4b). For the lamellar bright particles determined as MoC phase, the increase in size is more significant.

The addition into vacuum chamber $10 \mathrm{sccm} \mathrm{C}_{2} \mathrm{H}_{2}$ flow leads to the formation of significant quantity of $\mathrm{MoC}$ phase, which reaches the quantity of nitrogen phases. The deconvolution of complex and broadened diffraction lines in $2 \Theta$ angle range $70^{\circ}-87^{\circ}$ revealed the existence of $\mathrm{MoN}$ and $\mathrm{MoC}$ phases except for present $\mathrm{Mo}_{2} \mathrm{~N}$ phase. The quantity of the phases is approximately equal.

The ridges are visible (Fig. 3) for $\mathrm{Mo}_{0.68} \mathrm{~N}_{0.32}$ and $\mathrm{Mo}_{0.64} \mathrm{C}_{0.07} \mathrm{~N}_{0.29}$ coatings which do not show carbon phases in XRD diffraction pattern, Fig. 5. The increase in carbon in $\mathrm{Mo}(\mathrm{C}) \mathrm{N}$ coatings decreases the grain size to about 100-200 nm (Fig. 3c). Such surface microstructure means that acetylene (source of carbon) introduced into the vacuum chamber has not only distributed on the surface in the form of crystallization nuclei, but its quantity is sufficient for stoichiometric MoC phase. In "Torsion" regime, there are dark particles dispersed, probably MoN (indicator 2, Fig. 5c) and white lamellar inclusions presumptive $\mathrm{MoC}$ phase (indicator 3, Fig. 5c). The first phase particles dimension is about $20-50 \mathrm{~nm}$, and the white phase is about $400-600 \mathrm{~nm}$. Based on observation of the microstructure in the lateral force regime, it can be noted that the number of phases in both colors increased. They are uniformly distributed on the surface.

The increase in the acetylene flow rate in the vacuum chamber to $15 \mathrm{sccm}$ results in achieving the maximum intensity of $\mathrm{MoC}$ phase diffraction lines in the diffraction pattern. The 

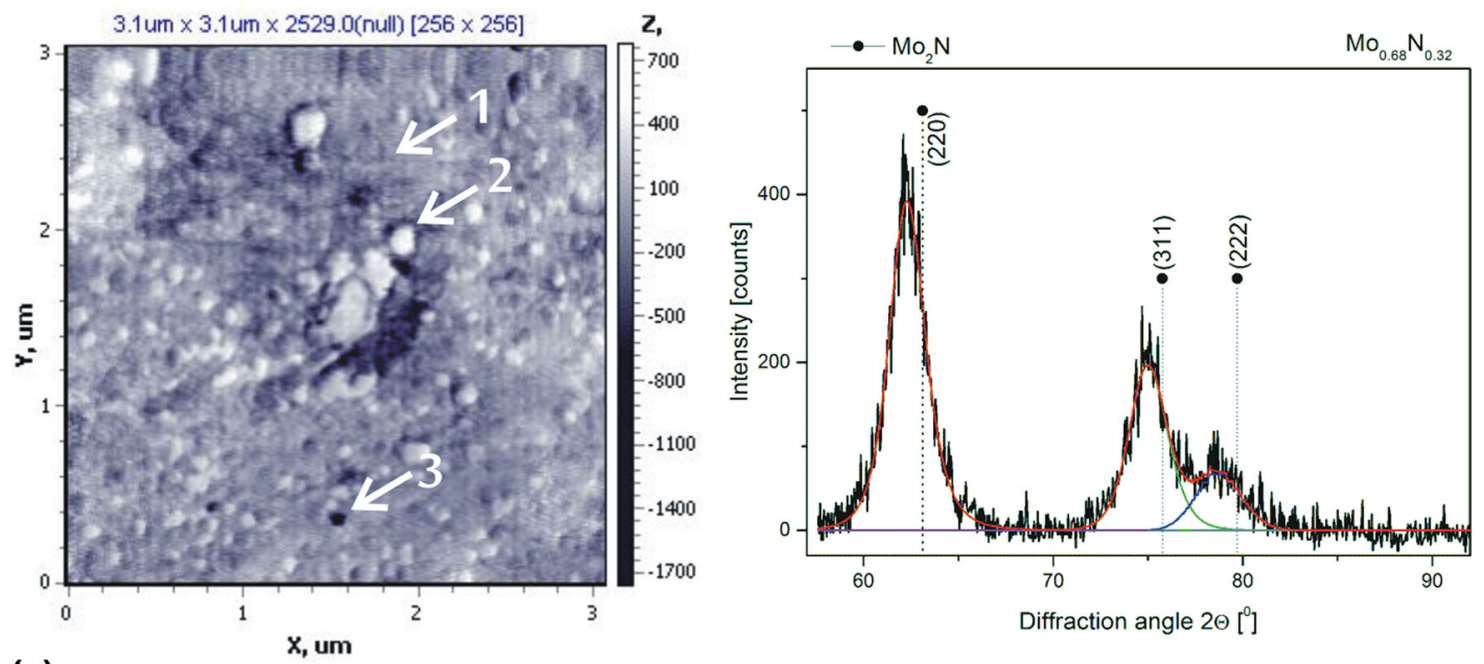

(a)
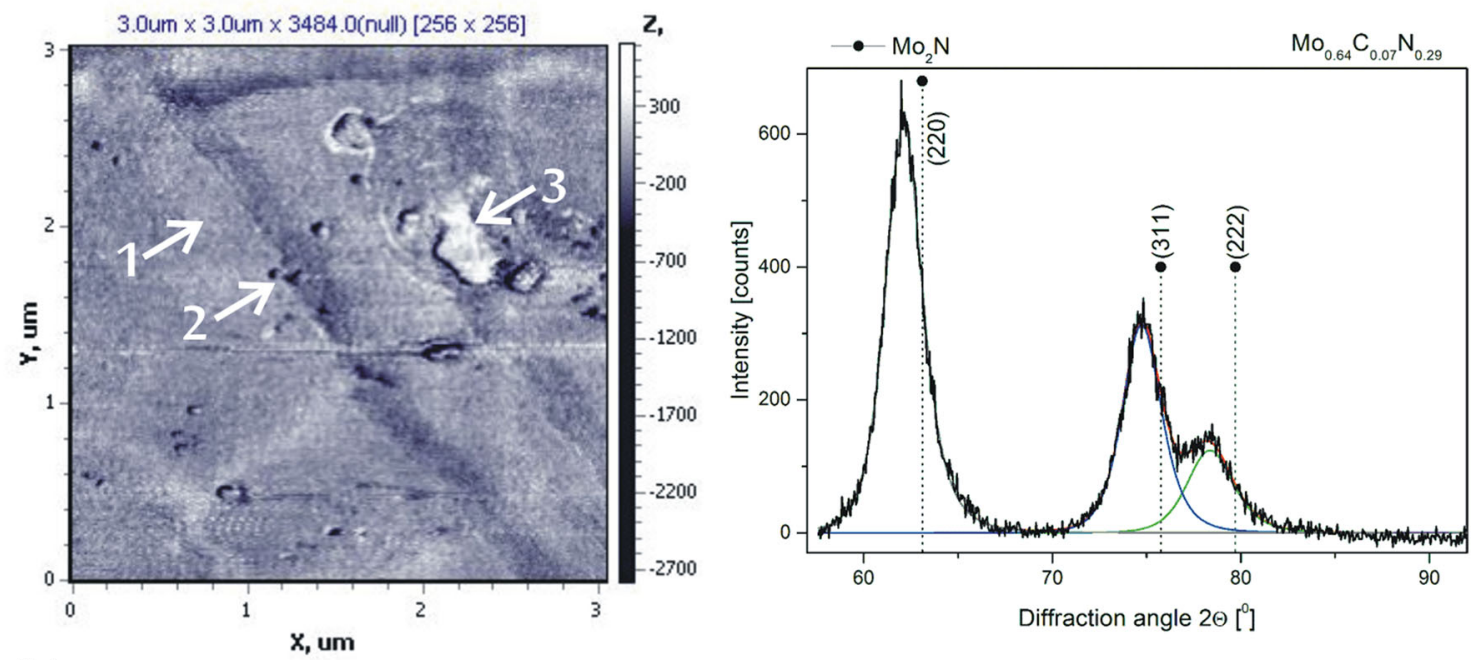

(b)
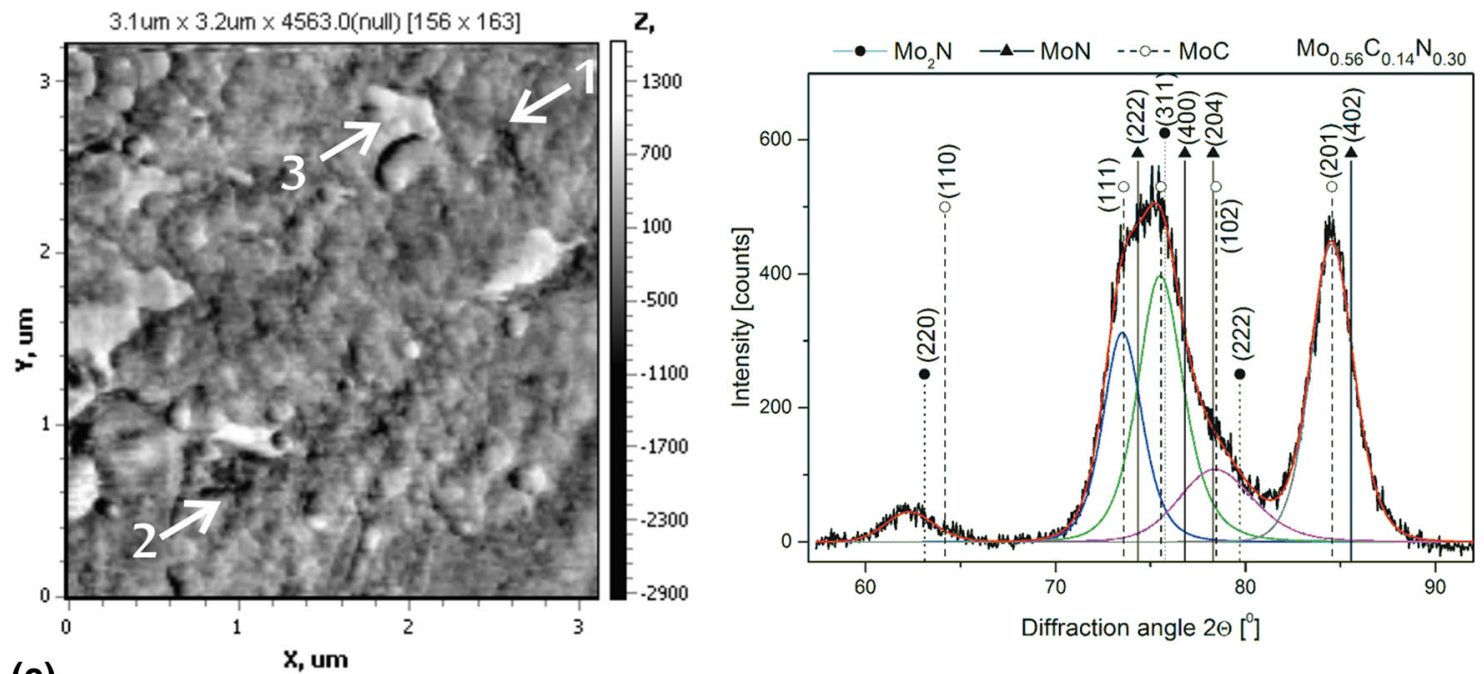

(c)

Fig. 5 Microstructure of $\mathrm{Mo}(\mathrm{C}) \mathrm{N}$ coatings with carbon obtained with AFM in "Torsion" regime, left side, compared with XRD dates, right side. Acetylene flow rate: (a) $0 \mathrm{sccm}$, (b) $5 \mathrm{sccm}$, (c) $10 \mathrm{sccm}$, (d) $15 \mathrm{sccm}$, (e) $20 \mathrm{sccm}$ 

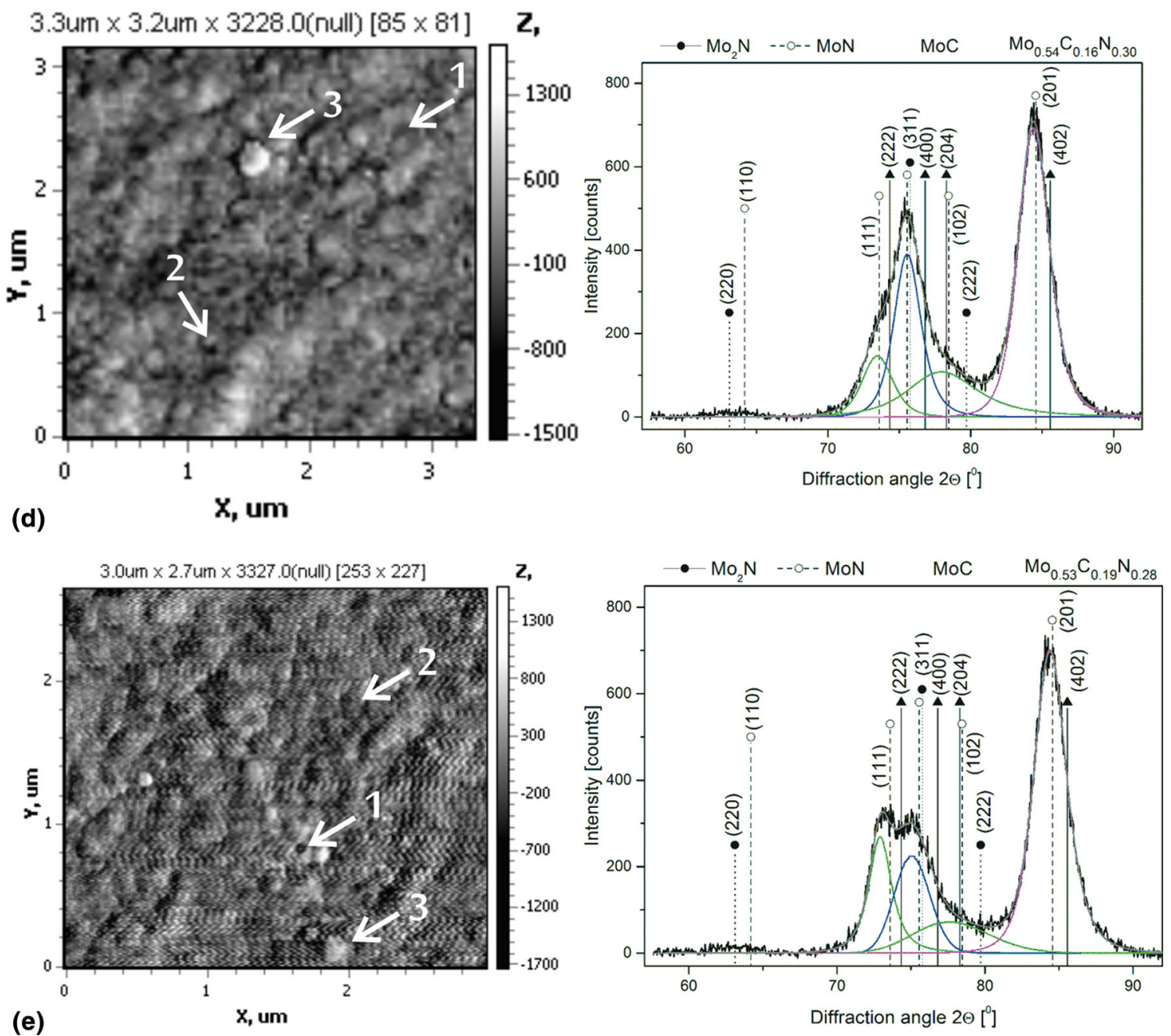

Fig. 5 continued

Table 3 Size of phases observed in AFM measurements

The size of phases

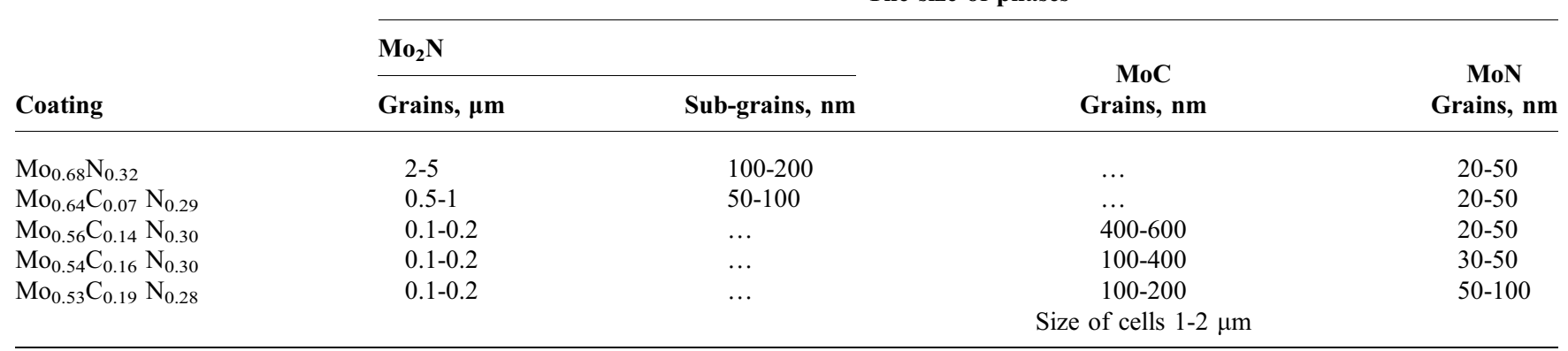

further rise of the acetylene flow rate to $20 \mathrm{sccm}$ does not change intensity in $\mathrm{MoC}$ diffraction lines. Probably, the formation of $\mathrm{MoC}$ phase could be finished. A transformation of the main $\mathrm{Mo}_{2} \mathrm{~N}$ phase to mixture of $\mathrm{Mo}_{2} \mathrm{~N}, \mathrm{MoN}$ and $\mathrm{MoC}$ phases takes place. The structure type is changing drastically (Fig. 5c). The dispersed phase appears fast in the coating with a uniform grain size of 100-200 nm (indicator 1, Fig. 5c). Bright and dark particles (indicator 2, Fig. 5c) are uniformly distributed on the surface. We suppose that lamellar bright particles of MoC phase compared with one shown in Fig. 5(b) have more developed surface. Their size decreased significantly to $100-400 \mathrm{~nm}$ (indicator 3, Fig. 5c).

In the $\mathrm{Mo}_{0.53} \mathrm{C}_{0.19} \mathrm{~N}_{0.28}$ coating formed in vacuum chamber in acetylene flow rate of $20 \mathrm{sccm}$, the surface microstructure type, that is dispersed, grains do not change (Fig. 5e) and are the same as for coating formed in $15 \mathrm{sccm}$ of acetylene. The difference is in grain size - in this coating they were decreased. The size of dark, probably MoN, dispersed phase is $50-100 \mathrm{~nm}$ 

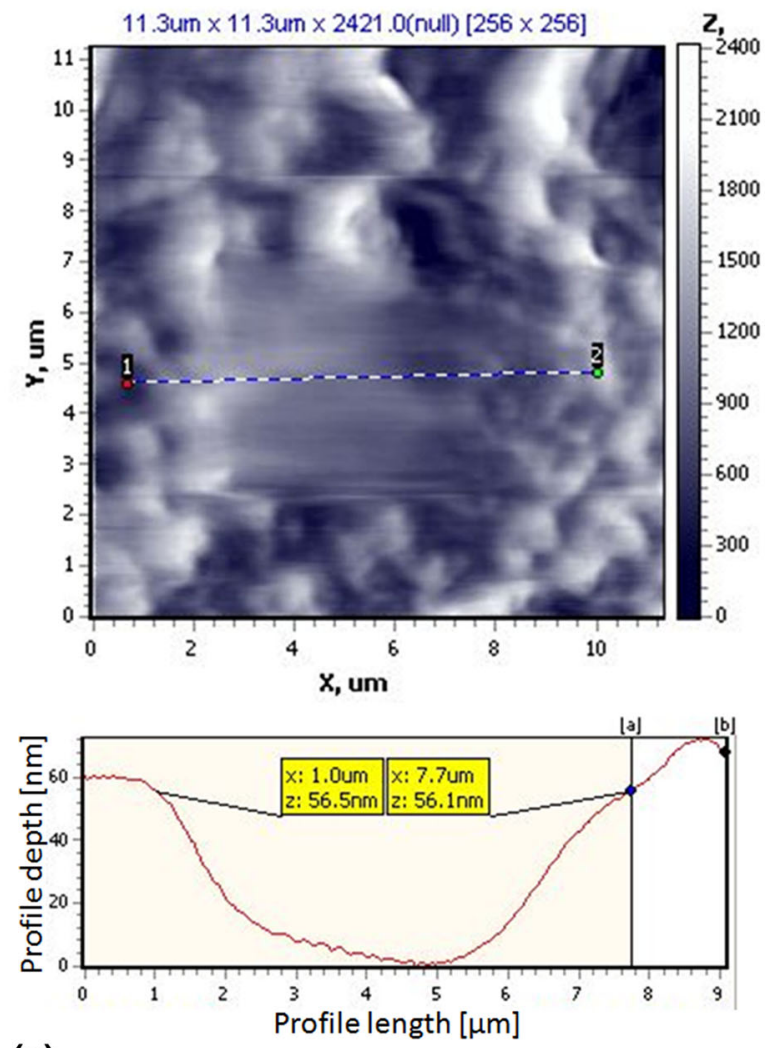

(a)
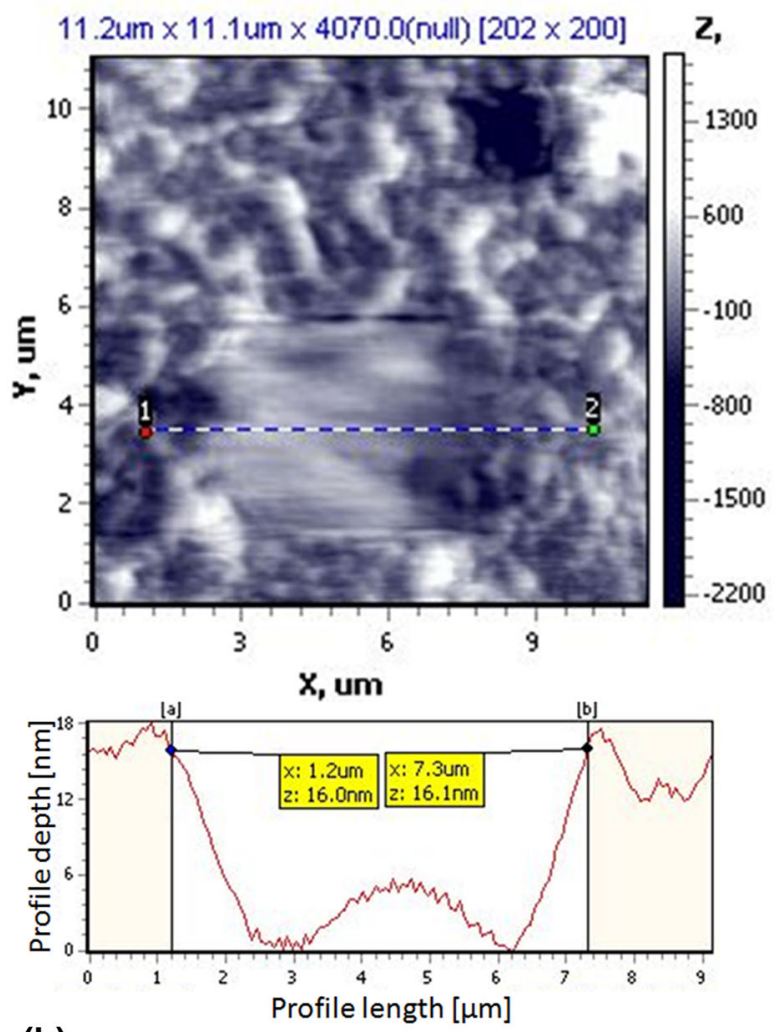

(b)

Fig. 6 Results of the wear and wear profile using AFM of: (a) $\mathrm{Mo}_{0.68} \mathrm{~N}_{0.32}$ and (b) $\mathrm{Mo}_{0.56} \mathrm{C}_{0.14} \mathrm{~N}_{0.30}$ coatings. The dashed line (1-2) indicates the position of wear profile in wear area (indicator 1, Fig. 5e). The other particles MoC (indicator 2, Fig. 5e) and $\mathrm{Mo}_{2} \mathrm{~N}$ (indicator 3, Fig. 5e) have similar size-100-200 $\mathrm{nm}$. The main structure of dispersed particles is ordered. The grains are arranged into a honeycomb structure with a cell size of about $1 \mu \mathrm{m}$. The size of phases observed in AFM measurements in all coatings is gathered in Table 3.

Due to refinement of grains and for proper assessment of grain dimensions, the AFM measurements on the square $10 \times 10 \mu \mathrm{m}$ ought to be taken. The roughness resulted from these tests reflects the features of coating formation correctly. The features of microstructure of $\mathrm{Mo}(\mathrm{C}) \mathrm{N}$ coating like microdrops significantly affect the value of roughness on square $20 \times 20 \mu \mathrm{m}$ or more. Its surface distribution has a random nature. The smaller size of square causes incorrect cells structure. So the coating with 7.1 at.\% C shows $19 \mathrm{~nm}$ roughness, while the common MoN coating is only $10 \mathrm{~nm}$. This confirms an idea that at acetylene flow rate of $5 \mathrm{sccm}$ in vacuum chamber, $\mathrm{MoC}$ phase does not form. Instead of that, the grain refinement of nitriding phases occurs and as an effect the more shaped grain boundaries are formed and the additional ridges appear on the surface. Therefore, the value of roughness decreases to $11.2 \mathrm{~nm}$ for coatings deposited at $\mathrm{C}_{2} \mathrm{H}_{2}$ flow rate of $10 \mathrm{sccm}$ and to $9.4 \mathrm{~nm}$ at $15 \mathrm{sccm}$. The MoC phase formed as the rounded nanosized grains smoothes the coating surface. The further increase in roughness to $15.2 \mathrm{~nm}$ is connected with the appearance of chains and ridges from grains.

Hard coating shows usually high wear resistance, and as consequence the depth of wear tracks was several nanometers. The relief of the surface and craters were more apparent than the depth of obtained wear tracks. The results of wear tests on $\mathrm{Mo}_{2} \mathrm{~N}$ (acetylene flow rate- $0 \mathrm{sccm}$ ) and $\mathrm{Mo}(\mathrm{C}) \mathrm{N}$ deposited using acetylene flow rate of $10 \mathrm{sccm}$ are presented in Fig. 6 . Below images of worn surface of the coatings the profiles of wear tracks are added.

The depth of wear (volume of material removed from the surface) was $56 \mathrm{~nm}\left(9.0 \times 10^{-19} \mathrm{~m}^{3}\right)$ for $\mathrm{Mo}_{2} \mathrm{~N}$ coating and 16 $\mathrm{nm}\left(2.6 \times 10^{-19} \mathrm{~m}^{3}\right)$ for $\mathrm{Mo}(\mathrm{C}) \mathrm{N}$ coating deposited using 10 sccm of acetylene. Specific wear rate calculated according to Archard's formula is $14.6 \times 10^{-14} \mathrm{~m}^{3} / \mathrm{N}$ m and $4.2 \times 10^{-14} \mathrm{~m}^{3} /$ $\mathrm{N}$ m, respectively. It means that $\mathrm{MoCN}$ coatings can present better wear resistance compared to $\mathrm{Mo}_{2} \mathrm{~N}$ coating.

\section{Conclusion}

The presence of MoC phase is not observed for low carbon concentration in $\mathrm{Mo}(\mathrm{C}) \mathrm{N}$ coatings corresponding to acetylene flow rate of $5 \mathrm{sccm}$ in vacuum chamber. This phase starts to form with higher than $5 \mathrm{sccm} \mathrm{C}_{2} \mathrm{H}_{2}$ flow rate and appears as the grain structure instead of cells structure. With further increase in the acetylene flow rate, the grain size in $\mathrm{Mo}(\mathrm{C}) \mathrm{N}$ coating decreases. In coatings deposited at $\mathrm{C}_{2} \mathrm{H}_{2}$ flow rate of $20 \mathrm{sccm}$, the grains form the ordered cell structure with the grain size of $100-200 \mathrm{~nm}$ and the cell size of $1 \mu \mathrm{m}$.

The phase composition of coatings changes with the increase in carbon concentration in $\mathrm{Mo}(\mathrm{C}) \mathrm{N}$. The initial $\mathrm{Mo}_{2} \mathrm{~N}$ phase, which is characterized by cubic lattice, is replaced by hexagonal $\mathrm{MoN}$ and $\mathrm{MoC}$ phases. It seems the coatings with carbon have a better view tribological application. However, in-depth studies must be carried out to confirm this conclusion. 


\section{Acknowledgments}

The study was supported by ImBeing project, Towards Intelligent Micro-Bearings-Tribological Aspects, (IMBeing-FP7PEOPLE-2013-IRSES-612593) within the 7th Framework Programme of the European Commission.

\section{Open Access}

This article is distributed under the terms of the Creative Commons Attribution 4.0 International License (http://creativecommons. org/licenses/by/4.0/), which permits unrestricted use, distribution, and reproduction in any medium, provided you give appropriate credit to the original author(s) and the source, provide a link to the Creative Commons license, and indicate if changes were made.

\section{References}

1. S. Hogmark, S. Jacobson, and M. Larsson, Design and Evaluation of Tribological Coatings, Wear, 2000, 246, p 20-33

2. J. Musil, Hard and Superhard Nanocomposite Coating, Surf. Coat. Technol., 2000, 125, p 322-330

3. Z. Peng, H. Miao, W. Wang, S. Yang, C. Liu, and L. Qi, Hard and Wear-Resistant Titanium Nitride Films for Ceramic Cutting Tools by Pulsed High Energy Density Plasma, Surf. Coat. Technol., 2003, 166, p $183-188$

4. B. Navinsek, P. Panjan, and I. Milosev, Industrial Applications of CrN (PVD) Coatings, Deposited at High and Low Temperatures, Surf. Coat. Technol., 1997, 97, p 182-1891

5. P.H.M. Böttger, L. Braginsky, V. Shklover, E. Lewin, J. Patscheider, D.G. Cahill, and M. Sobiech, Hard Wear-Resistant Coatings with Anisotropic Thermal Conductivity for High Thermal Load Applications, J. Appl. Phys., 2014, 116, p 013507

6. P.H. Mayrhofer, R. Rachbauer, R. D. Holec, F. Rovere, and J.M. Schneider, Protective Transition Metal Nitride Coatings, in: S. Hasmi (Ed.) Comprehensive Materials Processing, Elsevier, Amsterdam, 2014, p 355-388

7. X. Zhu, D. Yue, C. Shang, M. Fan, and B. Hou, Phase Composition and Tribological Performance of Molybdenum Nitride Coatings Synthesized by IBAD, Surf. Coat. Technol., 2013, 228, p S184S189

8. F. Perry, A.W. Baouchi, J.H. Petersen, and S.D. Pozder, Surf. Coat. Technol., 1992, 54(55), p 261-265
9. T. Polcar, L. Cvrček, P. Široký, and R. Novák, Tribological Characteristics of $\mathrm{Cr}(\mathrm{CN})$ Coatings at Elevated Temperature, Vacuum, 2005, 80, p 113-116

10. L. Karlsson, L. Hultman, M.P. Johansson, J.E. Sundgren, and H. Ljungcrantz, Growth, Microstructure, and Mechanical Properties of Arc Evaporated $\mathrm{TiC}_{\mathrm{x}} \mathrm{N}_{1-\mathrm{x}}(0 \leq \mathrm{x} \leq 1)$ films, Surf. Coat. Technol., 2000, 126, p 1-14

11. J. Almer, M. Odén, and G. Håkansson, Microstructure, Stress and Mechanical Properties of Arc-Evaporated Cr-C-N Coatings, Thin Solid Films, 2001, 385, p 190-197

12. Q. Liu, T. Liu, Q.F. Fang, F.J. Liang, and J.X. Wang, Preparation and Characterization of Nanocrystalline Composites Mo-C-N Hard Films, Thin Solid Films, 2006, 503, p 79-84

13. G. An and G. Liu, Preparation of Ultramicro Molybdenum Carbide Powders and Study on Wear Properties of Their Coating, Rare Metals., 2011, 30, p 262-266

14. Y. Zhao, K. Kamiya, K. Hashimoto, and S. Nakanishi, In Situ $\mathrm{CO}_{2}$ Emission Assisted Synthesis of Molybdenum Carbonitride Nanomaterial as Hydrogen Evolution Electrocatalyst, J. Am. Chem. Soc., 2015, 137, p 110-113

15. Z.G. Yuan, J.F. Yang, X.P. Wang, Z.J. Cheng, and Q.F. Fang, Characterization and Properties of Quaternary Mo-Si-C-N Coatings Synthesized by Magnetron Sputtering Technique, Surf. Coat. Technol., 2011, 205, p 3307-3312

16. D.V. Shtansky, A.V. Bondarev, Ph.V. Kiryukhantsev-Korneev, T.C. Rojas, V. Godinho, and A. Fernández, Structure and Tribological Properties of MoCN-Ag Coatings in the Temperature Range of 25$700{ }^{\circ} \mathrm{C}$, Appl. Surf. Sci., 2013, 273, p 408-414

17. A.V. Bondarev, Ph.V. Kiryukhantsev-Korneev, D.A. Sidorenko, and D.V. Shtansky, A New Insight into Hard Low Friction MoCN-Ag Coatings Intended for Applications in Wide Temperature Range, Mater. Des., 2016, 93, p 63-72

18. H.-J. Butt, B. Cappella, and M. Kappl, Force Measurements with the Atomic Force Microscope: Technique, Interpretation and Applications, Surf. Sci. Rep., 2005, 59, p 1-152

19. M. Andreyev, V. Anishchik, L. Markova, and T. Kuznetsova, Ion-Beam Coatings Based on Ni and Cr with Ultradispersed Diamonds-Structure and Properties, Vacuum, 2005, 78, p 451-454

20. A. Gilewicz, R. Jedrzejewski, A.E. Kochmanska, and B. Warcholinski, Structure of MoCN Films Deposited by Cathodic Arc Evaporation, Thin Solid Films, 2015, 577, p 94-96

21. B. Bhushan, Nanotribology and Nanomechanics, an Introduction, 2nd ed., Springer, Berlin, 2008

22. A. Gilewicz, B. Warcholinski, and D. Murzynski, The Properties of Molybdenum Nitride Coatings Obtained by Cathodic Arc Evaporation, Surf. Coat. Technol., 2013, 236, p 149-158

23. H.H. Hausner, Coatings of High-Temperature Materials, Springer, New York, 1996 